Science in the Spanish and Portuguese

Empires, 1500-1800 



\title{
Science in the Spanish and Portuguese Empires, 1500-1800
}

\author{
Edited by \\ Daniela Bleichmar, Paula De Vos, \\ Kristin Huffine, and Kevin Sheehan
}

y

STANFORD UNIVERSITY PRESS

STANFORD, CALIFORNIA 


\section{Stanford University Press \\ Stanford, California}

(C)2009 by the Board of Trustees of the Leland Stanford Junior University.

All rights reserved.

This book has been published with the assistance of the USC-Huntington Early Modern Studies Institute; the USC College of Letters, Arts, and Sciences; and the History Department, Graduate School, College of Arts and Sciences, and Center for Latino and Latin American Studies at Northern Illinois University.

No part of this book may be reproduced or transmitted in any form or by any means, electronic or mechanical, including photocopying and recording, or in any information storage or retrieval system without the prior written permission of Stanford University Press.

Printed in the United States of America on acid-free, archival-quality paper

Library of Congress Cataloging-in-Publication Data

Science in the Spanish and Portuguese empires, I500-I $800 /$ edited by Daniela Bleichmar ... [et al.]. p. $\mathrm{cm}$.

Includes bibliographical references and index. ISBN 978-0-8047-5358-6 (cloth : alk. paper)

I. Science--Latin America--History. 2. Science--Spain--Colonies--History. 3. Science--Portugal--Colonies--History. 4. Science--Latin America--Historiography. 5. Latin America--History--To I830. I. Bleichmar, Daniela, I973QI27.L38S36 2009 